\title{
Congenital aortic valve disease with rupture of mitral chordae tendineae
}

\author{
Simon Joseph, Richard Emanuel, Marvin Sturridge, and Eckhardt Olsen \\ From The Middlesex Hospital; Cardiothoracic Institute; and The National Heart Hospital, London
}

$A$ new clinical entity is described in which free aortic regurgitation from congenital aortic valve disease caused rupture of the chordae to the anterior leaflet of the mitral valve in 7 men aged 45 to 63 years (mean 52 years); 2 of the patients also had rupture of chordae to the posterior leaflet. Comparing these patients with those with ruptured mitral chordae in association with rheumatic heart disease and patients with spontaneous chordal rupture, differences were evident. No patient had a history of rheumatic fever and none had active infection. The typical clinical presentation was of acute mitral regurgitation into a small left atrium, with severe pulmonary oedema which was often resistant to medical treatment. The cause of chordal rupture in these patients was in part the result of progressive left ventricular dilatation, of direct trauma to the anterior cusp of the mitral valve, and possibly of a genetic factor. The anatomical features of both aortic and mitral valves are described, and in 3 histology of the mitral valve was available; 2 had myxomatous degeneration similar to that seen in patients with spontaneous chordal rupture, and in 1 there was degeneration of collagen tissue. All patients were treated surgically but the mortality was high (5 out of 7, 70\%). Early operation with replacement of the aortic and mitral valves is recommended if this high mortality is to be reduced.

Chordal rupture without obvious cause was described 40 years ago (Frothingham and Hass, 1934) but its importance has only become recognized relatively recently (Bailey and Hickam, 1944; Sanders et al., 1965; Roberts, Braunwald, and Morrow, 1966; Klughaupt et al., 1969; Eisenmann, 1973; Sutton, Chatterjee, and Caves, 1973). During the past decade, it has been recognized as a common cause of mitral regurgitation and is now believed to account for between 20 and 30 per cent of all cases of isolated mitral regurgitation (Ellis, Frye, and McGoon, 1966; Eisenmann, 1973). Previously rupture of mitral chordae was generally attributed to rheumatic heart disease with or without infective endocarditis (Osmundson, Callahan, and Edwards, 1958; Barrillon, Maurice, and Lenègre, 1967; Sanders et al., 1967; Littler, Epstein, and Coulshed, 1973; Eisenmann, 1973).

Other causes of ruptured chordae include coronary artery disease, Marfan's disease, trauma, and the 'floppy valve syndrome' (Childress, Maroon, and Genovese, 1966; Barrillon et al., 1967; Simpson, Nora, and McNamara, 1969;

Received 1 December 1975.
Bailey, Vera, and Hirose, 1969; Edwards, 1971; Cooley et al., 1972; Eisenmann, 1973; Goodman, Kimbiris, and Linhart, 1974; Aranda et al., 1975). Rare associations include pregnancy, left atrial myxoma, osteogenesis imperfecta, Ehlers-Danlos syndrome, gargoylism, acute rheumatic fever, scarlet fever, aneurysm of sinus of Valsalva, congestive cardiomyopathy, and hypertrophic cardiomyopathy (Frew, 1931; Wigle, 1964; Childress et al., 1966; Barrillon et al., 1967; Sanders et al., 1967; Hwang and Lam, 1968; Soulié et al., 1969; Sloman, Hunt, and Hare, 1969; Edwards, 1971; Caves and Paneth, 1972; Lainée et al., 1972; Ghahramani et al., 1972; Wood, Thomas, and Braimbridge, 1973; Wise, 1974).

This report describes 7 patients with severe aortic regurgitation caused by congenital aortic valve disease and ruptured mitral chordae tendineae, an association not previously reported. In these patients there was no history of rheumatic fever or evidence of rheumatic heart disease. One patient only had had infective endocarditis. In all patients, chordae to the anterior mitral cusp were involved and 6 of the 7 patients presented with acute heart failure. 


\section{Clinical data}

The clinical details of the 7 patients are described. Haemodynamic data, and operative and pathological findings are summarized in the Table.

\section{Case 1}

A man, known to have valvular heart disease since the age of 39 years, presented with acute left heart failure at the age of 62 . There was no history of rheumatic fever. He had signs of severe aortic and mitral regurgitation, with clinical evidence of left and right ventricular hypertrophy and left heart failure. The chest radiograph showed pronounced cardiomegaly with pulmonary oedema and the electrocardiogram confirmed severe left ventricular hypertrophy and atrial fibrillation.

Emergency surgery without cardiac catheterization was undertaken. The aortic valve was calcified and bicuspid, with calcification in the rudimentary

TABLE Clinical, haemodynamic, and pathological data

\begin{tabular}{|c|c|c|c|c|c|c|c|c|c|c|c|c|c|}
\hline \multirow{3}{*}{$\begin{array}{l}\text { Case } \\
\text { No. }\end{array}$} & \multirow[t]{3}{*}{ Sex } & \multirow{3}{*}{$\begin{array}{l}\text { Age } \\
\text { at } \\
\text { opn }\end{array}$} & \multirow{3}{*}{$\begin{array}{l}\text { Cardiac } \\
\text { rhythm }\end{array}$} & \multirow{3}{*}{$\begin{array}{l}\text { Duration } \\
\text { of } \\
\text { symptoms }\end{array}$} & \multirow{3}{*}{$\begin{array}{l}\text { Duration } \\
\text { of final } \\
\text { illness }\end{array}$} & \multirow{3}{*}{$\begin{array}{l}\text { Additional } \\
\text { diagnosis }\end{array}$} & \multicolumn{5}{|c|}{ Haemodynamic data $(\mathrm{mmHg})$} & \multirow{2}{*}{\multicolumn{2}{|c|}{$\begin{array}{l}\text { Angiographic } \\
\text { assessment }\end{array}$}} \\
\hline & & & & & & & $P C V$ & $P C V$ & $P A$ & $P A$ & $L V$ & & \\
\hline & & & & & & & mean & 'v' wave & & mean & $e d p$ & $A R$ & $M R$ \\
\hline 1 & $\mathbf{M}$ & 62 & AF & $23 \mathrm{yrs}$ & $3 / 12$ & - & $24^{\star}$ & $55^{\star}$ & $55-60 \dagger / 0$ * & $20 \star$ & - & - & - \\
\hline 2 & $\mathbf{M}$ & 63 & SR & $7 / 12$ & $7 / 12$ & AVs & 20 & 35 & $55 / 12$ & - & 20 & $2 / 4$ & $2 / 4$ \\
\hline
\end{tabular}

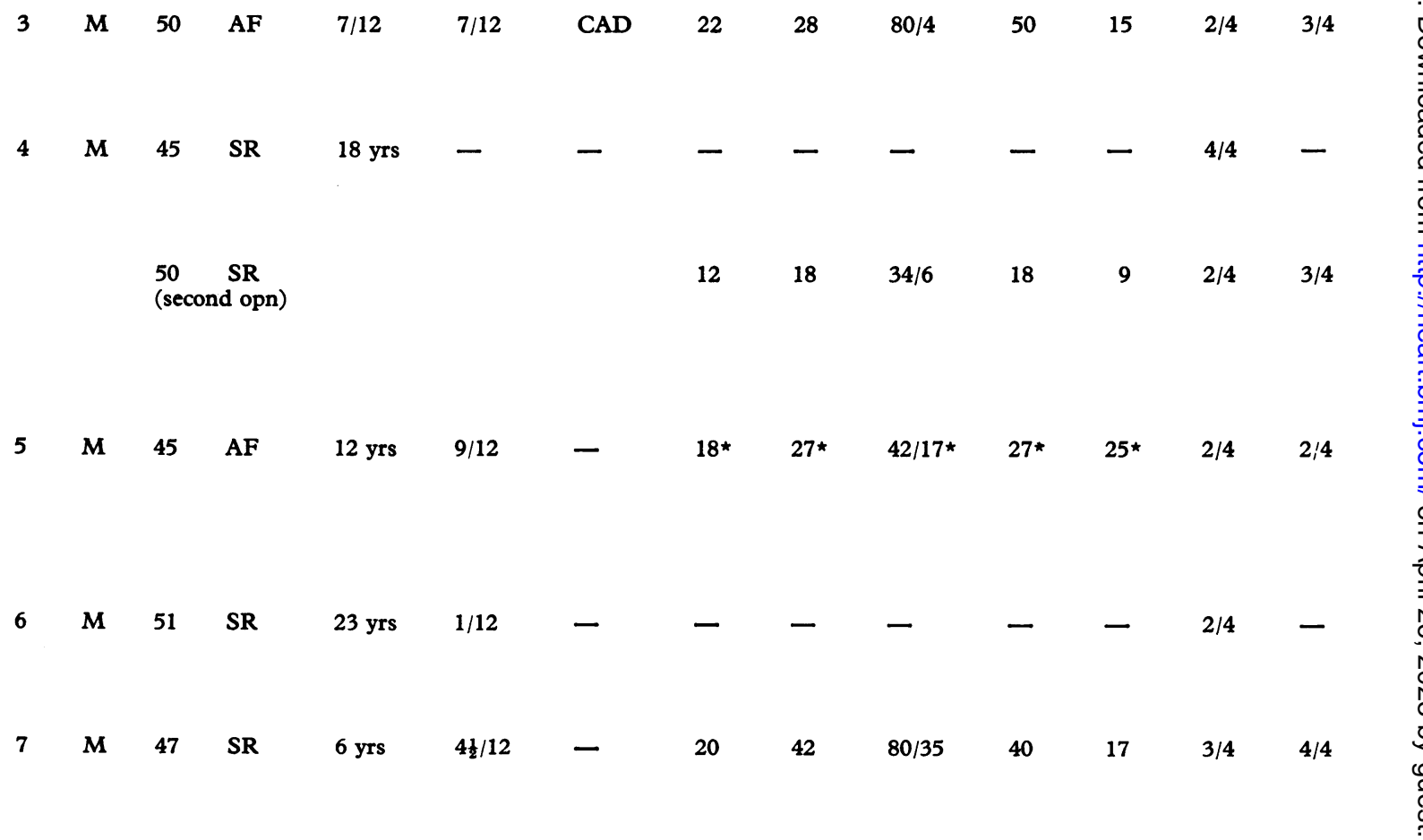

^Pressures obtained at operation.

+ Right ventricular pressure.

Abbreviations: AF, atrial fibrillation: AML, anterior mitral leaflet; AR, aortic regurgitation; AVS, aortic valve stenosis; CAD, coronary artery disease; LV edp, left ventricular end diastolic pressure; MR, mitral regurgitation; PA, pulmonary artery; PCV, pulmonary capillary venous pressure; PML, posterior mitral leaflet; SR, sinus rhythm.

Conversion from Traditional to SI Units: $1 \mathrm{mmHg} \approx 0.133 \mathrm{kPa}$. 
commissure; the non-coronary cusp was shortened, allowing free regurgitation. The mitral valve annulus was very dilated; the anterior cusp was a little thickened and chordae to its centre were ruptured. The posterior cusp was normal and the chordae intact. Both valves were replaced with Starr-Edwards prostheses.

Initial progress was satisfactory but four months after operation he developed left heart failure and died at home.

\begin{tabular}{|c|c|c|c|}
\hline \multirow{2}{*}{$\begin{array}{l}\text { Mitral valve } \\
\text { Macroscopical } \\
\text { appearance }\end{array}$} & \multicolumn{3}{|c|}{ Aortic valve } \\
\hline & Histology & $\begin{array}{l}\text { Macroscopic } \\
\text { appearance }\end{array}$ & al histology \\
\hline $\begin{array}{l}\text { AML_2 rupt. } \\
\text { central chordae; } \\
\text { PML_normal; } \\
\text { annulus dilated } \\
\text { AML_-3-4 rupt. } \\
\text { ant-lat. chordae; } \\
\text { PML—normal; } \\
\text { annulus normal }\end{array}$ & $\begin{array}{l}\text { Myxomatous } \\
\text { degeneration; } \\
\text { fibroelastic } \\
\text { thickening } \\
\text { Collagenous } \\
\text { thickening and } \\
\text { degeneration }\end{array}$ & $\begin{array}{l}\text { Bicuspid } \\
\text { calcified } \\
\text { Bicuspid } \\
\text { calcified }\end{array}$ & $\begin{array}{l}\text { Myxomatous } \\
\text { degeneration; } \\
\text { fibroelastic } \\
\text { thickening } \\
\text { Collagenous } \\
\text { thickening, } \\
\text { degeneration, } \\
\text { and } \\
\text { calcification }\end{array}$ \\
\hline $\begin{array}{l}\text { AML_rupt. ant- } \\
\text { lat. chordae; } \\
\text { PML_voluminous; } \\
\text { annulus } \\
\text { dilated }\end{array}$ & - & $\begin{array}{l}\text { Bicuspid } \\
\text { thickened }\end{array}$ & 一 \\
\hline $\begin{array}{l}\text { AML-2 rupt. } \\
\text { chordae; volumi- } \\
\text { nous; } \\
\text { PML-voluminous; } \\
\text { annulus dilated }\end{array}$ & - & $\begin{array}{l}\text { Bicuspid } \\
\text { calcified }\end{array}$ & $\begin{array}{l}\text { Thickened and } \\
\text { fibrosed }\end{array}$ \\
\hline $\begin{array}{l}\text { AML_same } \\
\text { chordae rupt.; } \\
\text { voluminous; } \\
\text { PML_thickened; } \\
\text { voluminous; } \\
\text { annulus dilated }\end{array}$ & $\begin{array}{l}\text { Myxomatous } \\
\text { degeneration; } \\
\text { collagenous } \\
\text { thickening and } \\
\text { degeneration; } \\
\text { increased } \\
\text { vascularity }\end{array}$ & - & - \\
\hline $\begin{array}{l}\text { AML_rupt. } \\
\text { chordae at med. } \\
\text { commissure; } \\
\text { PML_rupt. } \\
\text { chordae at med. } \\
\text { commissure; } \\
\text { annulus dilated }\end{array}$ & 一 & $\begin{array}{l}\text { Bicuspid } \\
\text { calcified }\end{array}$ & $\begin{array}{l}\text { Nodular } \\
\text { calcific } \\
\text { fibrosis }\end{array}$ \\
\hline $\begin{array}{l}\text { AML_rupt. } \\
\text { chordae to med. } \\
\text { half; } \\
\text { PML-1 rupt. chord } \\
\text { annulus normal }\end{array}$ & da ; & $\begin{array}{l}\text { Bicuspid } \\
\text { calcified } \\
\text { 'floppy' }\end{array}$ & - \\
\hline $\begin{array}{l}\text { AML二1 rupt. } \\
\text { central chorda; } \\
\text { PML - normal; } \\
\text { annulus dilated }\end{array}$ & - & Bicuspid & - \\
\hline
\end{tabular}

Histological examination of the aortic valve showed thickening of the valve leaflets caused by fibroelastic tissue with foci of calcification. Superimposed on the deformed face was a layer of collagen tissue, which suggested aortic regurgitation of some duration. Myxomatous degeneration was prominent. The mitral valve showed thickening of collagen tissue and extensive myxomatous degeneration in the centre of the anterior leaflet in the position of the zona spongiosa. Similar changes were present in the ruptured chordae. There was no increased vascularity.

\section{Case 2}

A 63-year-old man with no rheumatic history presented with sudden onset of left heart failure, and effort angina. He had features of aortic valve disease with stenosis and regurgitation. On the chest radiograph there was considerable cardiomegaly with pulmonary venous congestion and aortic valve calcification, and electrocardiogram showed severe left ventricular hypertrophy. Cardiac catheterization confirmed aortic valve stenosis and regurgitation; and also showed important mitral regurgitation, without stenosis.

At operation the aortic valve was bicuspid and heavily calcified with a transverse opening. The chordae to the anterolateral part of the mitral anterior cusp were ruptured but the mitral valve was otherwise normal. Both valves were replaced with Starr-Edwards prostheses. The patient made an uncomplicated recovery apart from the onset of atrial fibrillation.

Microscopically the acrtic valve leaflets were thickened, particularly towards the free edge. This thickening consisted of collagen tissue and foci of calcification. There was also some degeneration of the collagen tissue. Vascularity was not increased. The mitral valve showed uniform thickening caused by collagen tissue, which, particularly in the central portion of the valve leaflet, was associated with extensive degenerative changes; again the vascularity was not increased.

\section{Case 3}

A 50-year-old man with no previous cardiac or rheumatic history presented with sudden onset of left heart failure. Clinically he had the signs of congestive cardiac failure, mitral regurgitation, and atrial fibrillation. Radiographic information is not available. Cardiac catheterization confirmed mitral regurgitation but aortography was not performed. He was discharged on medical treatment but 4 months later was readmitted with further cardiac failure and renal failure that later required haemodialysis. He was transferred to London 3 months later and at this time the chest radiograph showed considerable cardiomegaly. The electrocardiogram confirmed atrial fibrillation and left ventricular 
hypertrophy. A second cardiac catheterization confirmed severe mitral regurgitation, pronounced pulmonary hypertension, and important aortic regurgitation which had been suspected clinically. In view of the abrupt onset of symptoms the possibility of ruptured mitral chordae was considered.

At operation the aortic valve was bicuspid with a calcified rudimentary commissure, the cusps were thickened with rolled edges, and the valve was clearly regurgitant. The mitral annulus was very large; most chordae to the anterolateral end of the anterior cusp had ruptured allowing free mitral regurgitation. The posterior cusp was voluminous, but the chordae were intact. Both valves were replaced with Starr-Edwards prostheses.

Postoperative progress was uneventful but in spite of adequate anticoagulation he developed a cerebral embolism 14 months after operation, with transient dysphasia and hemiparesis. Two years later he suffered an anteroseptal myocardial infarction but made a satisfactory recovery.

Valve histology is not available.

\section{Case 4}

A man aged 27 years without a history of rheumatic fever developed acute left ventricular failure. He was treated medically until the age of 37 years when he deteriorated and was admitted to hospital. Clinically he had severe aortic regurgitation which was confirmed by aortography. Surgery was advised but the patient declined. He was again treated medically but deteriorated progressively. At the age of 45 years when readmitted the chest radiograph showed considerable cardiomegaly, with pulmonary venous congestion, and electrocardiogram confirmed sinus rhythm with left atrial and severe left ventricular hypertrophy. In view of the earlier haemodynamic findings, a second cardiac catheterization was not performed.

At surgery the aortic valve was bicuspid, calcified, and grossly regurgitant. Severe mitral regurgitation was caused by 2 ruptured chordae to the anterior mitral cusp and the annulus was dilated. There was also a jet lesion on the anterior cusp of the mitral valve with shallow ulceration. A mitral annuloplasty was performed and the chordae were sutured; the aortic valve was replaced with a pulmonary autograft (Gonzalez-Lavin et al., 1970a) and a pulmonary homograft was used to replace the pulmonary valve. He made a satisfactory recovery but he developed signs of mitral regurgitation 19 months later; at this time cardiac catheterization showed mild aortic regurgitation and moderate mitral regurgitation. He developed progressive symptoms but again refused surgery for a further 4 years when he was readmitted in extremis. At operation, which was undertaken as a matter of urgency, the anterior mitral leaflet was ballooned with thickening of the free margin. The repaired chordae of the anterior leaflet had ruptured and most of the unruptured chordae were slender though two, adjacent to the commissures, had thickened. The posterior leaflet was also thickened and ballooned into the left atrium but all the chordae were intact. There was moderate aortic regurgitation resulting from prolapse of one cusp of the pulmonary autograft, and a perforation of a second suggested previous infection. Degeneration of the pulmonary homograft had produced free pulmonary regurgitation. The pulmonary valve was replaced with an aortic homograft and the mitral and aortic valves with Starr-Edwards prostheses. The patient deteriorated because of infection of the homograft and died 2 weeks after the second operation from cardiac and renal failure.

Histology of the mitral valve showed uniform thickening and a prominent zona spongiosa with myxomatous degeneration, as well as degeneration of collagen tissue. The chordae showed similar changes. Both the degenerative areas gave a positive reaction with alcian blue stain. In the centre of the anterior mitral valve leaflet, thick-walled small vessels were identified. In view of the patient's previous operation, this increased vascularity could have been the result of the previous surgical intervention or, secondly, of inflammation such as infective endocarditis, but there was no history of this and no vegetations were seen. The pulmonary homograft showed some degenerative changes of collagen tissue and the body of the leaflet was totally devoid of nuclei, but the surfaces were covered with fibroblasts. One leaflet (anterior cusp) showed recent fibrin superimposition. There was no evidence of infection. The pulmonary autograft showed uniform thickening, together with mild degenerative changes of collagen tissue, and in these areas the nuclei were reduced. The leaflet in the position of the non-coronary cusp showed total destruction of normal architecture.

Pathology of the patient's original aortic valve is not available.

\section{Case 5}

This man had no history of rheumatic fever, and heart disease was first diagnosed at the age of 33 years. He presented at the age of 42 years with moderate aortic regurgitation, having deteriorated with the onset of atrial fibrillation, but there was no other evidence of mitral valve disease. At the age of 44 he developed severe acute left ventricular failure 
with considerable cardiomegaly and the signs of aortic and mitral regurgitation. The electrocardiogram and chest radiograph confirmed severe left ventricular enlargement, and the diagnosis of aortic and mitral regurgitation was confirmed by angiography.

Surgery was initially refused but was undertaken as a matter of urgency 7 months later after a recurrence of heart failure with tricuspid regurgitation. The aortic valve was bicuspid with massive nodular calcification and fibrosis. It was replaced with a Starr-Edwards prosthesis. The mitral annulus was grossly enlarged with pliable cusps and ruptured chordae at the medial end of both anterior and posterior leaflets; an annuloplasty was performed with imbrication at the level of the ruptured chordae; the valve was subsequently competent. The tricuspid ring was also dilated and required an annuloplasty. After the operation severe neurological complications developed and he died 9 days later.

Histology of the mitral valve is not available.

\section{Case 6}

A man developed breathlessness at the age of 37 years and had an attack of infective endocarditis at the age of 38 years when heart disease was first diagnosed. He had further attacks of infective encocarditis at 43 and 47 years. He presented at the age of 51 years with evidence of moderate aortic regurgitation, confirmed by aortography and slight mitral regurgitation. Chest radiograph at that time showed mild cardiomegaly with no evidence of left atrial enlargement, and electrocardiogram confirmed sinus rhythm with moderate left ventricular hypertrophy. He resfonded initially to medical treatment and was then lost to follow-up for 7 years. He returned at the age of 58 years; surgery was advised but he refused operation in spite of progressive symptoms.

Two years later at the age of 60 years he developed acute left ventricular failure. Chest radiograph showed further increase in heart size with pulmonary oedema, and electrocardiogram confirmed progressive left ventricular hypertrophy. Emergency surgery was undertaken without prior cardiac catheterization.

The aortic valve, which was congenitally bicuspid, was large and 'floppy'. There was minimal calcification, with prolapse of the non-coronary cusp. The mitral valve was grossly regurgitant because of rupture of the chordae from the medial half of the anterior cusp. In addition there was a single ruptured chorda from the posterior cusp. Both valves were replaced with Starr-Edwards prostheses.
In spite of an adequate cardiac output immediately after the operation, his circulation deteriorated and he developed acute renal failure. Medical treatment, including peritoneal dialysis, failed to prevent his death on the fourth postoperative day.

Valve histology is not available.

\section{Case 7}

A male patient had no rheumatic history but a cardiac murmur was heard during childhood. Aortic regurgitation was diagnosed at 41 years and he presented at the age of 44 years with sudden onset of left and right heart failure. He had signs of severe aortic and mitral regurgitation. The chest radiograph showed considerable cardiomegaly and pulmonary venous congestion, and an electrocardiogram confirmed left and right ventricular and left atrial hypertrophy. Angiography confirmed the diagnosis.

At surgery the aortic valve was bicuspid and uncalcified and the root large with a diameter of $3.3 \mathrm{~cm}$; regurgitation was the result of cusp attenuation and insufficiency. The mitral ring was also grossly dilated with a diameter of about $8 \mathrm{~cm}$; the valve cusps were thin and attenuated and one chorda to the central part of the anterior cusp was ruptured. Both valves were replaced with StarrEdwards prostheses but the patient died from uncontrollable haemorrhage from the left coronary artery.

Valve histology is not available.

\section{Discussion}

The clinical features of acute mitral regurgitation from ruptured chordae tendineae have been reviewed recently (Roberts and Perloff, 1972; Littler et al., 1973; Sutton et al., 1973). Some of the points which help to distinguish it from rheumatic mitral regurgitation with intact chordae are the short history, persistence of sinus rhythm, high left atrial pressure caused by a small non-compliant left atrium (Baxley et al., 1973) and the unusual radiation of systolic murmurs. Before the syndrome became well recognized it was often mistaken for aortic stenosis because of the radiation of the mitral systolic murmur to the base of the heart (Osmundson et al., 1958). This was particularly so when the chordae to the posterior mitral cusp were involved. When chordae to the anterior cusp were ruptured the radiation of the murmur was more typical of rheumatic mitral regurgitation. Some authors, however, have found that the radiation of the murmur was an unreliable guide to the nature of the regurgitation (Sutton et al., 1973; Littler et al., 
1973). A further difficulty arises with the systolic ejection murmur which usually accompanies florid aortic regurgitation; this may mask the murmur of mitral regurgitation, especially when the latter is conducted to the base.

Ruptured chordae in association with rheumatic mitral and aortic valve disease with and without infective endocarditis is well recognized (Sanders et al., 1967; Shine et al., 1968; Gonzalez-Lavin, Lise, and Ross, 1970b). Other cases with aortic regurgitation have been recorded, but the nature of the valve lesions in these reports was not mentioned (Barrillon et al., 1967; Manhas et al., 1971). Rupture of mitral chordae associated with severe aortic regurgitation from a congenitally bicuspid aortic valve has not previously been reported.

Acute mitral regurgitation from chordal rupture frequently presents as unexpected left heart failure. This was so in 6 of our 7 patients. Four were in sinus rhythm and 4 had a small left atrium. As left heart failure in these cases was primarily mechanical, the result of ruptured chordae with subsequent prolapse of the anterior cusp and a dilated mitral annulus, it was not surprising that they failed to respond to medical treatment. In 6 , surgery was undertaken within 7 months of the onset of symptoms. In spite of this, 4 were emergency procedures and the operative mortality was high; 5 out of the 7 $(70 \%)$ died. If the mortality is to be reduced, the malignant course of mitral regurgitation from ruptured chordae must be recognized and surgery undertaken as soon as the diagnosis is made.

All 7 patients had bicuspid aortic valves; 6 were thickened and 4 were calcified. One valve was 'floppy' (Case 6) and aortic regurgitation in this case was caused by cusp prolapse. Histology was available on 4 of the aortic valves, one showed myxomatous degeneration (Case 1), while in another (Case 2) there were degenerative changes in the collagen tissue. In the remaining 2 , non-specific fibrosis and calcification were found.

In 5 cases rupture of mitral chordae was confined to the anterior leaflet; in the remaining 2 , chordae to both anterior and posterior cusps were involved. Five patients had considerable dilatation of the mitral annulus and in 2 there was excessive cusp tissue involving both leaflets in one and the posterior cusp in the other. There was no evidence in our patients that chordal rupture was caused by the more common aetiologies of rheumatic fever or infective endocarditis, except possibly in Case 6 where there was a history of bacterial endocarditis. In Case 4 the anterior leaflet of the mitral valve showed increased vascularity with thick walled vessels, which was thought to be caused by the previous mitral annuloplasty. Rheumatic endo- carditis seemed unlikely as the normal architecture, though distorted by thickening, was not destroyed. Infective endocarditis also seemed improbable because of the absence of recent or healed vegetations. Histological examination of the $3 \mathrm{mitral}$ valves available (Cases 1, 2, and 4) showed myxomatous degeneration together with degenerative changes in collagen tissue (Fig.), the latter being the only change seen in Case 2. The elastic tissue was often fragmented. These histological appearances were similar to those described in cases of spontaneous or idiopathic chordal rupture (Bailey and Hickam, 1944; Shine et al., 1968; Gerbode et al., 1969; Caulfield et al., 1971; Caves, Sutton, and Paneth, 1973). Similar pathology is probably responsible for the floppy valve syndrome where from 9 to 20 per cent may develop ruptured chordae (Read, Thal, and Wendt, 1965; Pomerance, 1969; Cooley et al., 1972). The 'floppy' or 'ballooning' mitral valve is probably responsible for the systolic click-late systolic murmur syndrome in which chordal rupture has also been reported (Goodman et al., 1974).

The macroscopical appearances of the normal mitral valve have been described in detail by Ranganathan et al. (1970). The anterior leaflet consists of rough and clear zones, while the posterior leaflet, like the tricuspid valve, has an additional basal zone. On average 25 chordae are present, 9 are inserted into the anterior leaflet, the majority into the rough zone, while 14 usually form part of the posterior leaflet. The remaining 2 chordae are inserted at the commissures (Lam et al., 1970). Basically the valve leaflets have two layers. The 'deformed' face which consists of elastic tissue, and the 'holding face' of collagen tissue. Not infrequently, an additional zone can be identified between these two layers, the so-called zona spongiosa (Gross and Kugel, 1931). When myxomatous degeneration is prominent, it is in a central position, so that it suggests an increase in the zona spongiosa. Frequently, however, degenerative changes in collagen tissue are also present. It may be that a prominent zona spongiosa is a genetically determined component which, in some cases, degenerates in later life, giving rise to the 'floppy valve' syndrome.

Caulfield et al. (1971) considered myxomatous degeneration to be enzymatic destruction of normal collagenous and elastic structure. The same authors noted the presence of blood vessels in normal chordae but reported fewer in degenerated zones. There is increasing evidence that ischaemia, which is known to cause papillary muscle dysfunction and rupture, is also a factor in chordal rupture (Sanders et al., 1967; Barrillon et al., 1967; Gerbode 


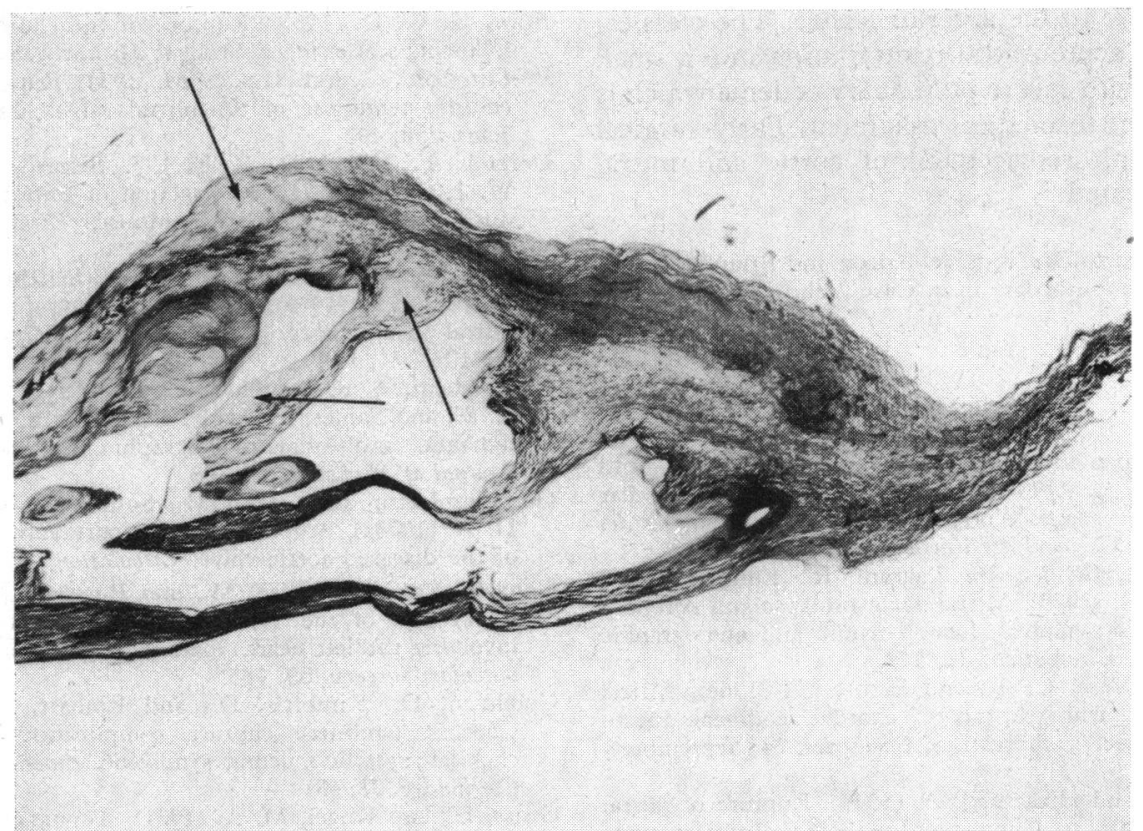

FIG. Photomicrograph (Weigert's elastic van Gieson. $\times 12$ ) from Case 4 showing distal portion of the anterior mitral leaflet and severed chordae. Areas of myxomatous degeneration in both the valve leaflet and chordae are marked with arrows.

et al., 1968; Klughaupt et al., 1969; Eisenmann, 1973; Caves et al., 1973; Aranda et al., 1975). It is generally agreed that in the physiological state it is the chordae to the anterior leaflet which are subjected to the greater stress (Chiechi, Lees, and Thompson, 1956). So it is somewhat surprising that in cases of spontaneous chordae rupture (i.e. without other obvious pathology) it is usually the posterior mitral leaflet that is affected (Sanders et al., 1965; Marchand et al., 1966; Raftery, Oakley, and Goodwin, 1966; Acar et al., 1968; Selzer et al., 1972). In the normal valve mechanical stress on the mitral chordae during ventricular systole is probably not great. Marchand et al. (1966) when repairing ruptured chordae, noted little tension on nylon threads used when they were exteriorized through the left ventricular wall. Similar views were expressed by Salisbury, Cross, and Rieben (1963) who found that stress borne by normal mitral chordae diminished after aortic valve opening and before the development of peak systolic pressure. Furthermore, rupture of normal chordae is not particularly common in conditions such as aortic stenosis where peak left ventricular pressure may be abnormally high.

Pre-existing abnormalities of the left ventricle and the mitral valve almost certainly increase chordal stress. Edwards and Burchell (1958) postulated that left ventricular dilatation from whatever cause altered the normal lie of chordae, in which they are parallel to the inflow tract, thus increasing the stress to which they were subjected. Aortic regurgitation not only has this effect by increasing the diastolic volume, but the regurgitant jet may impinge directly onto the anterior cusp of the mitral valve causing local trauma to the valve leaflet and chordae (Gonzalez-Lavin et al., 1970b). This probably explains why, in the presence of aortic regurgitation, it is usually the chordae to the anterior cusp of the mitral valve which are ruptured (Menges, Ankeney, and Hellerstein, 1964; Ellis et al., 1966; Littler et al., 1973; Eisemann, 1973). In addition, Shine et al. (1968) suggested that the rapid recoil of the left ventricle in early diastole contributed to the mechanical stress to which the chordae of the anterior mitral leaflet were subjected. In the 7 patients reported here all factors for increasing chordal stress were present; in addition there may have been a congenital fault in the mitral valve tissue.

We consider that this syndrome is a new clinical entity in which free aortic regurgitation from congenital aortic valve disease causes progressive left ventricular dilatation and direct trauma to the anterior cusp of the mitral valve. These factors combine, generally without infection, and lead to rupture 
of the chordae to the anterior leaflet. The classical picture is of acute mitral regurgitation into a small left atrium, with severe pulmonary oedema which is often resistant to medical treatment. Early surgical treatment with replacement of aortic and mitral valve is indicated.

We are indebted to Drs. Raphael Balcon and Brian Heard for permission to publish data from Case 2 and to Dr. Michael Honey for Case 7.

\section{References}

Acar, J., Caramanian, M., Perrault, M., Luxereau, P., and Arnaud, J. C. (1968). Les insuffisances mitrales par rupture de cordages d'origine dégénérative. Archives des Maladies du Coeur et des Vaisseaux, 61, 1724.

Aranda, J. M., Befeler, B., Lazzara, R., Embi, A., and Machado, H. (1975). Mitral valve prolapse and coronary artery disease: clinical, hemodynamic and angiographic correlations. Circulation, 52, 245.

Bailey, C. P., Vera, C. A., and Hirose, T. (1969). Mitral regurgitation from rupture of chordae tendineae due to 'steering wheel' compression. Geriatrics, 24 (September), 90.

Bailey, O. T., and Hickam, J. A. (1944). Rupture of mitral chordae tendineae. Clinical and pathological observations on seven cases in which there was no bacterial endocarditis. American Heart fournal, 28, 578.

Barrillon, A., Maurice, P., and Lenègre, J. (1967). L'insuffisance mitrale pure par rupture de cordages. Archives des Maladies du Coeur et des Vaisseaux, 60, 1086.

Baxley, W. A., Kennedy, J. W., Field, B., and Dodge, H. T. (1973). Hemodynamics in ruptured chordae tendineae and chronic rheumatic mitral regurgitation. Circulation, 48, 1288 .

Caulfield, J. B., Page, D. L., Kastor, J. A., and Sanders, C. A. (1971). Connective tissue abnormalities in spontaneous rupture of chordae tendineae. Archives of Pathology, 91, 537.

Caves, P. K., and Paneth, M. (1972). Acute mitral regurgitation in pregnancy due to ruptured chordae tendineae. British Heart fournal, 34, 541.

Caves, P. K., Sutton, G. C., and Paneth, M. (1973). Nonrheumatic subvalvular mitral regurgitation: etiology and clinical aspects. Circulation, 47, 1242.

Chiechi, M. A., Lees, W. M., and Thompson, R. (1956). Functional anatomy of the normal mitral valve. fournal of Thoracic Surgery, 32, 378.

Childress, R. H., Maroon, J. C., and Genovese, P. D. (1966). Mitral insufficiency secondary to ruptured chordae tendinae. Annals of Internal Medicine, 65, 232.

Cooley, D. A., Gerami, S., Hallman, G. L., Wukasch, D. C., and Hall, R. J. (1972). Mitral insufficiency due to myxomatous transformation: 'floppy valve syndrome'. Fournal of Cardiovascular Surgery, 13, 346.

Edwards, J. E. (1971). Mitral insufficiency resulting from 'overshooting' of leaflets. Circulation, 43, 606.

Edwards, J. E., and Burchell, H. B. (1958). Pathologic anatomy of mitral insufficiency. Proceedings of the Staff Meetings of the Mayo Clinic, 33, 497.

Ellis, F. H., Frye, R. L., and McGoon, D. C. (1966). Results of reconstructive operations for mitral insufficiency due to ruptured chordae tendineae. Surgery, 59, 165

Eisenmann, B. (1973). L'insuffisance mitrale par rupture de cordages. Possibilités chirurgicales. Fournal de Chirurgie, 105,361 .
Frew, H. W. O. (1931). Rupture of the chordae tendineae following scarlet fever. Glasgow Medical fournal, 115, 195.

Frothingham, C., and Hass, G. M. (1934). Rupture of normal chordae tendineae of the mitral valve. American Heart fournal, 9, 492.

Gerbode, F., Hill, J. D., Kelly, J. J., Selzer, A., and Kerth, W. J. (1968). Surgical correction of mitral insufficiency due to ruptured chordae tendineae. Circulation, 37-38, Suppl. 2, 119.

Gerbode, F., Kerth, W. J., Hill, J. D., Sanchez, P. A., and Puryear, G. H. (1969). Surgical treatment of non-rheumatic mitral insufficiency. Fournal of Cardiovascular Surgery, 10, 103.

Ghahramani, A. R., Arnold, J. R., Hilder, F. J., Sommer, L. S., and Samet, P. (1972). Left atrial myxoma: hemodynamic and phonocardiographic features. American fournal of Medicine, 52, 525.

Gonzalez-Lavin, L., Geens, M., Somerville, J., and Ross, D. N. (1970a). Autologous pulmonary valve replacement of the diseased aortic valve. Circulation, 42, 781.

Gonzalez-Lavin, L., Lise, M., and Ross, D. (1970b). The importance of the 'jet lesion' in bacterial endocarditis involving the left heart. Fournal of Thoracic and Cardiovascular Surgery, $\mathbf{5 9}, 185$.

Goodman, D., Kimbiris, D., and Linhart, J. W. (1974) Chordae tendineae rupture complicating the systolic click-late systolic murmur syndrome. American fournal of Cardiology, 33, 681.

Gross, L., and Kugel, M. A. (1931). Topographic anatomy and histology of the valves in the human heart. American Fournal of Pathology, 7, 445.

Hwang, W. S., and Lam, K. L. (1968). Rupture of chordae tendineae during acute rheumatic carditis. British Heart fournal, 30, 429.

Klughaupt, M., Flamm, M. D., Hancock, E. W., and Harrison, D. C. (1969). Nonrheumatic mitral insufficiency. Determination of operability and prognosis. Circulation, 39, 307.

Lam, J. H. C., Ranganathan, N., Wigle, E. D., and Silver, M. D. (1970). Morphology of the human mitral valve. I. Chordae tendineae: a new classification. Circulation, 41, 449.

Lainée, R., Acar, J., Aigueperse, J., Oustrières, G., and Couffin, J-P. (1972). Myxome de l'oriellette gauche et insuffisance mitrale par rupture de cordages. Annales de Médecine Interne, 123, 923.

Littler, W. A., Epstein, E. J., and Coulshed, N. (1973). Acute mitral regurgitation resulting from ruptured or elongated chordae tendineae. Auscultatory and phonocardiographic findings. Quarterly fournal of Medicine, 42, 87.

Manhas, D. R., Hessel, E. A., Winterscheid, L. C., Dillard, D. H., and Merendino, K. A. (1971). Repair of mitral incompetence secondary to ruptured chordae tendineae. Circulation, 43, 688.

Marchand, P., Barlow, J. B., Du Plessis, L. A., and Webster, I. (1966). Mitral regurgitation with rupture of normal chordae tendineae. British Heart fournal, 28, 746.

Menges, H., Ankeney, J. L., and Hellerstein, H. K. (1964). The clinical diagnosis and surgical management of ruptured mitral chordae tendineae. Circulation, 30, 8.

Osmundson, P. J., Callahan, J. A., and Edwards, J. E. (1958). Mitral insufficiency from ruptured chordae tendineae simulating aortic stenosis. Proceedings of the Staff Meetings of the Mayo Clinic, 33, 235.

Pomerance, A. (1969). Balloon deformity (mucoid degeneration) of atrioventricular valves. British Heart fournal, 31, 343.

Raftery, E. B., Oakley, C. M., and Goodwin, J. F. (1966). Acute subvalvar mitral incompetence. Lancet, 2, 360. 
Ranganathan, N., Lam, J. H. C., Wigle, E. D., and Silver, M. D. (1970). Morphology of the human mitral valve. II. The valve leaflets. Circulation, 41, 459.

Read, R. C., Thal, A. P., and Wendt, V. E. (1965). Symptomatic valvular myxomatous transformation (the floppy valve syndrome). A possible forme fruste of the Marfan syndrome. Circulation, 32, 897.

Roberts, W. C., Braunwald, E., and Morrow, A. G. (1966). Acute severe mitral regurgitation secondary to ruptured chordae tendineae. Clinical, hemodynamic, and pathologic considerations. Circulation, 33, 58.

Roberts, W. C., and Perloff, J. K. (1972). Mitral valvular disease. A clinicopathologic survey of the conditions causing the mitral valve to function abnormally. Annals of Internal Medicine, 77, 939.

Sanders, C. A., Austen, W. G., Harthorne, J. W., Dinsmore, R. E., and Scannell, J. G. (1967). Diagnosis and surgical treatment of mitral regurgitation secondary to ruptured chordae tendineae. New England fournal of Medicine, 276, 943.

Sanders, C. A., Scannell, J. G., Harthorne, J. W., and Austen, W. G. (1965). Severe mitral regurgitation secondary to ruptured chordae tendineae. Circulation, 31, 506.

Salisbury, P. F., Cross, C. E., and Rieben, P. A. (1963). Chordae tendineae tension. American fournal of Physiology, 205, 385.

Selzer, A., Kelly, J. J., Kerth, W. J., and Gerbode, F. (1972). Immediate and long-range results of valvuloplasty for mitral regurgitation due to ruptured chordae tendineae. Circulation, 45-46, Suppl. 1, 52.

Shine, K. I., DeSanctis, R. W., Sanders, C. A., and Austen, W. G. (1968). Combined aortic and mitral incompetence. Clinical features and surgical management. American Heart fournal, 76, 728.
Simpson, J. W., Nora, J. J., and McNamara, D. G. (1969). Marfan's syndrome and mitral valve disease: acute surgical emergencies. American Heart fournal, 77, 96.

Sloman, G., Hunt, D., and Hare, W. S. C. (1969). Acute mitral incompetence. Australasian Annals of Medicine, 18, 102.

Soulié, P., Daumet, Ph., Caramanian, M., Soulié, J., and Heulin, A. (1969). Anéurisme du sinus de Valsalva propagé dans le septum interventriculaire. Archives des Maladies $d u$ Coeur et des Vaisseaux, 62, 597.

Sutton, G. C., Chatterjee, K., and Caves, P. K. (1973). Diagnosis of severe mitral regurgitation due to nonrheumatic chordal abnormalities. British Heart fournal, 35, 877.

Wise, J. R. (1974). Mitral regurgitation due to rupture of chordae tendineae by calcified atrial myxoma. British Medical fournal, 2, 95.

Wigle, E. D. (1964). In discussion of W. P. Clelland's The results of surgical treatment of hypertrophic obstructive cardiomyopathy. In Cardiomyopathies (Ciba Foundation Symposium), p. 295. Ed. by G. E. W. Wolstenhome, and M. O'Connor. Churchill, London.

Wood, S. J., Thomas, J., and Braimbridge, M. V. (1973). Mitral valve disease and open heart surgery in osteogenesis imperfecta tarda. British Heart fournal, 35, 103.

Requests for reprints to Dr. Richard Emanuel, Cardiothoracic Institute, 2 Beaumont Street, London W1N 2DX. 